\title{
Active-source seismic survey on the northeastern Hawaiian Arch: insights into crustal structure and mantle reflectors
}

\author{
Akane Ohira ${ }^{1,2^{*}} \mathbb{0}$, Shuichi Kodaira ${ }^{1,2}$, Gregory F. Moore ${ }^{3}$, Mikiya Yamashita ${ }^{1}$, Toshiya Fujiwara ${ }^{4}$, Yuka Kaiho', \\ Seiichi Miura ${ }^{1}$ and Gou Fujie ${ }^{1}$
}

\begin{abstract}
Seismic refraction and multi-channel seismic reflection surveys were conducted on the northeastern Hawaiian Arch to examine the effect of hotspot volcanism on the seismic structure of the crust and uppermost mantle. The crustal thickness deduced from the refraction data was typical for oceanic crust, which suggests that magmatic underplating does not occur, at least in our survey area, although the crustal seismic velocity may be influenced by flexure of the lithosphere on the arch. We identified high $P$-wave velocities $(\sim 8.65 \mathrm{~km} / \mathrm{s})$ in the uppermost mantle parallel to the paleo-seafloor spreading direction, which indicates that the shallower mantle structure immediately below the Moho preserves the original structure formed at a mid-ocean ridge. Moreover, we observed wide-angle reflection waves at large offsets in ocean-bottom seismometer records. The travel time analysis results showed that these waves were reflected from mantle reflectors at depths of 30-85 km below the seafloor, which are considered to represent heterogeneities consisting of frozen melts created during the cooling of the plate.
\end{abstract}

Keywords: Hawaiian Arch, Ocean-bottom seismometer, Multi-channel seismic reflection data

\section{Background}

The Hawaiian Islands, which are situated in the center of the Pacific Plate, constitute one of the best-known volcanic island chains formed by a mantle plume (Wilson 1963; Morgan 1971). The volcanic centers are characterized by an age-progressive island chain on old seafloor caused by intraplate volcanism away from a mid-ocean ridge. The seafloor on the Hawaiian Arch (Fig. 1) surrounding the island chain is anomalously shallow, relative to normal seafloor of the same age (e.g., Crough 1978; Ribe 2004), because of plate flexure caused by the island load. Therefore, this oceanic lithosphere is older and colder than would be expected for this bathymetric depth alone. For this reason, the northern Hawaiian Arch is one of the feasible candidates for Project Mohole drilling (Ildefonse et al. 2010), a plan proposed in 1957 to drill

\footnotetext{
*Correspondence: ohira@jamstec.go.jp

1 Japan Agency for Marine-Earth Science and Technology (JAMSTEC),

Showa-machi 3173-25, Kanazawa-ku, Yokohama 236-0001, Japan

Full list of author information is available at the end of the article
}

a hole completely through the crust beneath the ocean (Hess 1959). However, the crustal structure around the islands is potentially affected by hotspot volcanism, making it difficult to target "typical" oceanic crust for drilling.

Around the Hawaiian Islands, several seismic refraction experiments, including the original refraction survey for Project Mohole in 1962 across the northern Hawaiian Arch (Shor and Pollard 1964), have been carried out with explosives (Fig. 1). These active-source studies revealed the basic seismic velocity structures of the crust and uppermost mantle beneath the Hawaiian Arch and around the island of Hawaii (Shor and Pollard 1964; Hill 1969; Zucca and Hill 1980; Zucca et al. 1982). Shor and Pollard (1964) reported that beneath the Hawaiian Arch, the mean depth to Moho is $10.4 \mathrm{~km}$ below sea level and it dips to $13 \mathrm{~km}$ beneath the Hawaiian Deep and the northern shelf off Maui. They showed that this variation in depth to the mantle between the arch and the deep is due to variations in the thicknesses of the sediment and volcanic layers which have a $P$-wave velocity $(V \mathrm{p})$ near $4.2 \mathrm{~km} / \mathrm{s}$. They also identified the different mantle $V \mathrm{p}$ 


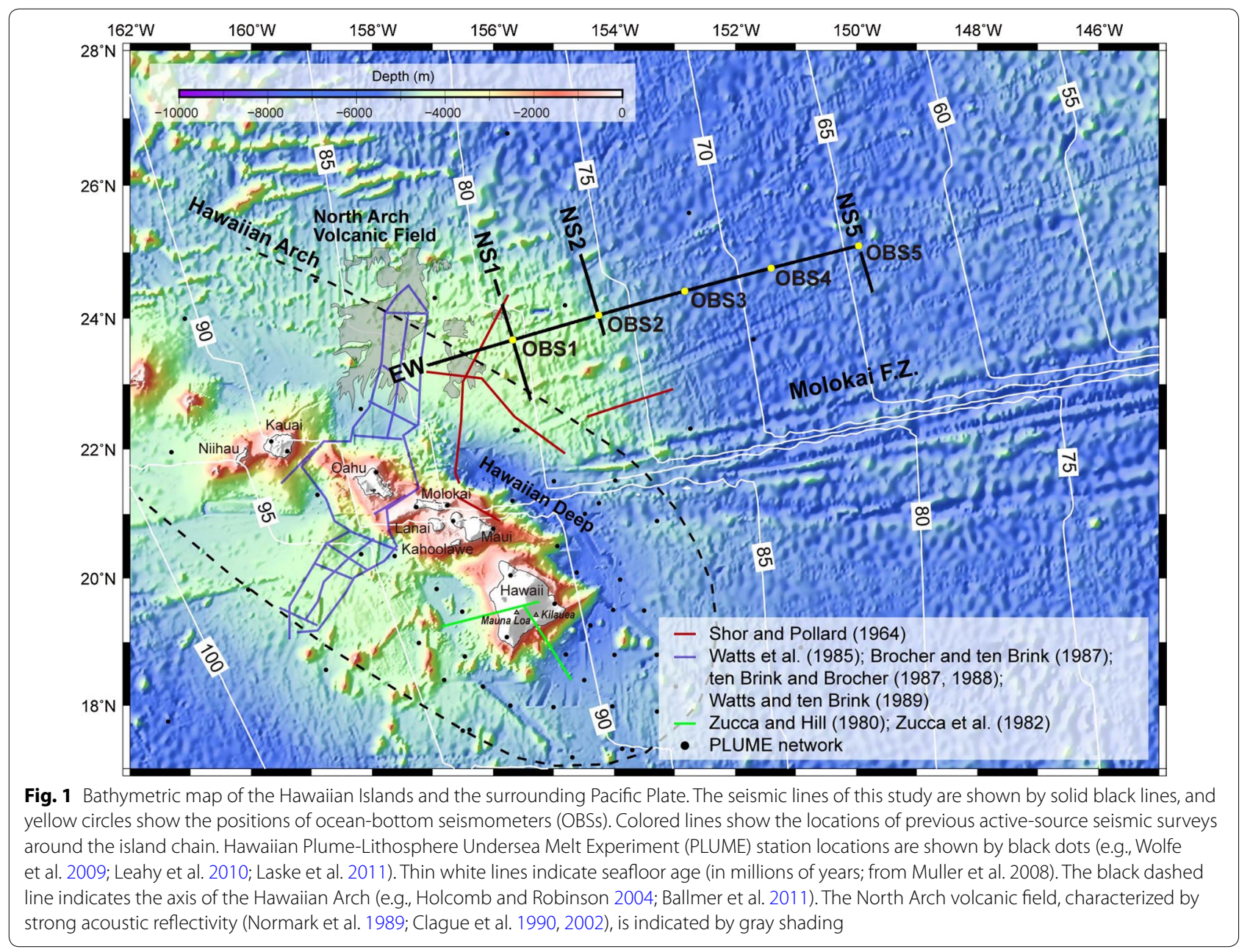

values of 8.1 and $8.7 \mathrm{~km} / \mathrm{s}$ along two survey lines crossing the arch at right angles. Zucca and Hill (1980) and Zucca et al. (1982), who conducted seismic refraction experiments adjacent to Kilauea and Mauna Loa volcanoes, showed that the oceanic crust bends downward beneath the island of Hawaii; as a result, the depth to Moho increases from about $10 \mathrm{~km}$ beneath the open ocean to roughly 13 and $18 \mathrm{~km}$ beneath the high, subaerial flanks of Kilauea and Mauna Loa, respectively (Hill and Zucca 1987).

To investigate flexural deformation of the oceanic crust due to the volcanic load of the Hawaiian ridge, coincident multi-channel seismic reflection and refraction data were obtained by a two-ship seismic survey near the islands of Oahu and Molokai (Watts et al. 1985; Brocher and ten Brink 1987; ten Brink and Brocher 1987, 1988; Watts and ten Brink 1989). The 1-D velocity structures and lateral extents of sedimentary, crustal, and subcrustal reflections revealed by these data suggest an interaction between upwelling magma from a hotspot source and bending stress caused by the products of the upwelling. Watts et al. (1985) suggested that the flexed oceanic crust beneath the island chain is underlain by a $4-\mathrm{km}$-thick deep crustal body with $V \mathrm{p}$ of $7.4-7.8 \mathrm{~km} / \mathrm{s}$, which they interpreted as a deep crustal sill complex.

These seismic experiments conducted around the island chain indicate that the crust thickens toward the islands. However, the "normal" crustal and upper mantle structure of the ocean basin (i.e., without any effects of a topographic swell), which must be known to determine the effect of the hotspot volcanism, have not yet been constrained by recent data acquisition techniques such as large-volume tuned airgun arrays, ocean-bottom seismometers (OBSs), and multi-channel streamer cables.

On the other hand, teleseismic receiver function analyses derived from seismic events recorded by the Hawaiian Plume-Lithosphere Undersea Melt Experiment (PLUME) seismic network, which consisted of nearly 70 seafloor sites and 10 land stations (e.g., Wolfe et al. 2009; Leahy et al. 2010; Laske et al. 2011), have constructed a 
much broader model of crustal structure than the models constructed by the active-source seismic experiments (e.g., Leahy et al. 2010). The analysis results show the crustal thickness of the Hawaiian swell and the region where magmatic underplating occurs. According to these results, the thickness of the total crustal column, which consists of preexisting crust and the underplated layer, ranges from approximately $7 \pm 1 \mathrm{~km}$ in non-underplated areas to $17 \pm 2 \mathrm{~km}$ under the islands. They inferred that magmatic underplating occurs beneath the northern Hawaiian Arch and that the presence of underplating is correlated with the shallow bathymetry of the Hawaiian swell, although the crustal structure on the northern Hawaiian Arch is not well constrained because of inadequate station coverage there (Leahy et al. 2010).

With regard to the deep lithospheric structure, the lithosphere-asthenosphere boundary has been imaged at $\sim 75-93 \mathrm{~km}$ depth beneath Hawaii by using S-to$P$ receiver functions (Rychert et al. 2013). On the other hand, long-offset profiling based on active-source seismic data in the Pacific basin has indicated the existence of seismic discontinuities shallower than the lithosphereasthenosphere boundary (Ohira et al. 2017b). Therefore, although the main purpose of the OBS deployment was to obtain the crustal $V \mathrm{p}$ to constrain the character of the crust and for use in processing multi-channel seismic (MCS) reflection data, we also attempted to image the deep lithospheric structure by designing a long-offset (approximately $750 \mathrm{~km}$ ) survey line, as described later ("Reflectors in the oceanic lithosphere").

\section{Study area}

To investigate the detailed seismic structure of the crust and uppermost mantle, we carried out an active-source seismic refraction and reflection survey across the northeastern Hawaiian Arch from August to October 2017 (Fig. 1). The age of the seafloor around our survey area ranges from 65 to $85 \mathrm{Ma}$ (Müller et al. 2008), and the estimated half-spreading rate is intermediate $(\sim 40 \mathrm{~mm} /$ year). Our survey lines extend from the ocean basin to the northern Hawaiian Arch and comprise lines both parallel and perpendicular to the seafloor spreading direction. The seafloor depth ranges from 4000 to $5500 \mathrm{~m}$ along the survey lines.

A submarine suite of young alkalic lava flows, known as the North Arch volcanic field, was previously found on the seafloor north of Oahu by side-scan sonar mapping (Normark et al. 1989; Clague et al. 1990, 2002). These lava flows cover an area of $\sim 25,000 \mathrm{~km}^{2}$ at water depths of 3900-4380 m (gray shaded areas in Fig. 1), and they are estimated to have erupted at $0.5-1.15 \mathrm{Ma}$ (Clague et al. 1990; Dixon et al. 1997; Clague and Dixon 2000;
Frey et al. 2000; Yang et al. 2003) in response to the loading of the Hawaiian Islands (Moore 1970).

\section{Data acquisition and processing}

For the acquisition of seismic data, five OBSs were deployed by R/V Marcus G. Langseth and recovered by R/V Kilo Moana. A tuned airgun array (volume 7800 cubic inches) mounted on R/V Kairei was fired at a depth of $10 \mathrm{~m}$ at intervals of $50 \mathrm{~m}$ along EW, NS2, and NS5 lines, and at intervals of 50 and $200 \mathrm{~m}$ along the NS1 line. MCS data were also collected with a 444-channel, 6000 -m-long streamer cable with a $12.5-\mathrm{m}$ interval between hydrophones, towed at a depth of $12 \mathrm{~m}$. Multibeam bathymetric data were collected with a SeaBeam 3012 echo sounder on R/V Kairei and EM 122 echo sounders on R/V Marcus G. Langseth and R/V Kilo Moana.

In this study, we deployed OBSs sparsely, at intervals of $150 \mathrm{~km}$, along only the EW line, because the main purpose of our refraction survey was to constrain the crustal structure as described above. We also attempted to observe the long-offset wide-angle reflection phases from mantle reflectors recorded by a previous long-offset OBS survey (Ohira et al. 2017b). Because the OBS deployment was sparse, we modeled the crustal velocity structure by applying a simple forward 2-D ray tracing approach (Zelt and Smith 1992; Fujie et al. 2008) to all OBS data. We assigned pick uncertainties between 0.05 and $0.2 \mathrm{~s}$, depending on the signal-to-noise ratio, to the travel times. In addition, we applied a travel time mapping method (Fujie et al. 2006) to reflection phases at large offsets to image the deep lithospheric structure. Each OBS was relocated by using direct water-wave arrivals. The observed waveforms were band-pass-filtered $(5-20 \mathrm{~Hz})$, and adjacent traces within the 200-m offset range were stacked to improve the signal-to-noise ratio.

We applied a conventional data processing flow to the MCS reflection data: format conversion, band-pass filtering, datum correction, trace editing, $\mathrm{F}-\mathrm{X}$ deconvolution, fan filtering, tau-P deconvolution, amplitude recovery, predictive deconvolution, velocity analysis, normal moveout correction, Radon demultiple, inner and outer trace muting, common depth point stacking, post-stack Kirchhoff time migration, top muting, and automatic gain control. For depth conversion of the time-migrated images, we used a velocity model obtained from the travel time analysis of the OBS data.

\section{Data description and results MCS reflection profiles}

Here, we summarize the overall character of the MCS sections with a focus on the igneous basement and Moho characteristics, which we then use along with 
the OBS refraction data to construct a seismic velocity model. The seismic reflection profiles show that the seafloor topography is generally rougher along the EW line than along the NS lines (Fig. 2); we attribute this difference to the presence of NNW-SSE-trending abyssal hills that developed at a mid-ocean ridge
(Normark et al. 1989), as shown by the multi-beam bathymetric data (Fig. 3). Within the distance range of 15-110 km along the EW line and along part of the NS1 line, the seafloor is smooth and the reflectivity at the seafloor and the basement is high (Fig. 4); these areas are east of the main region of the North Arch

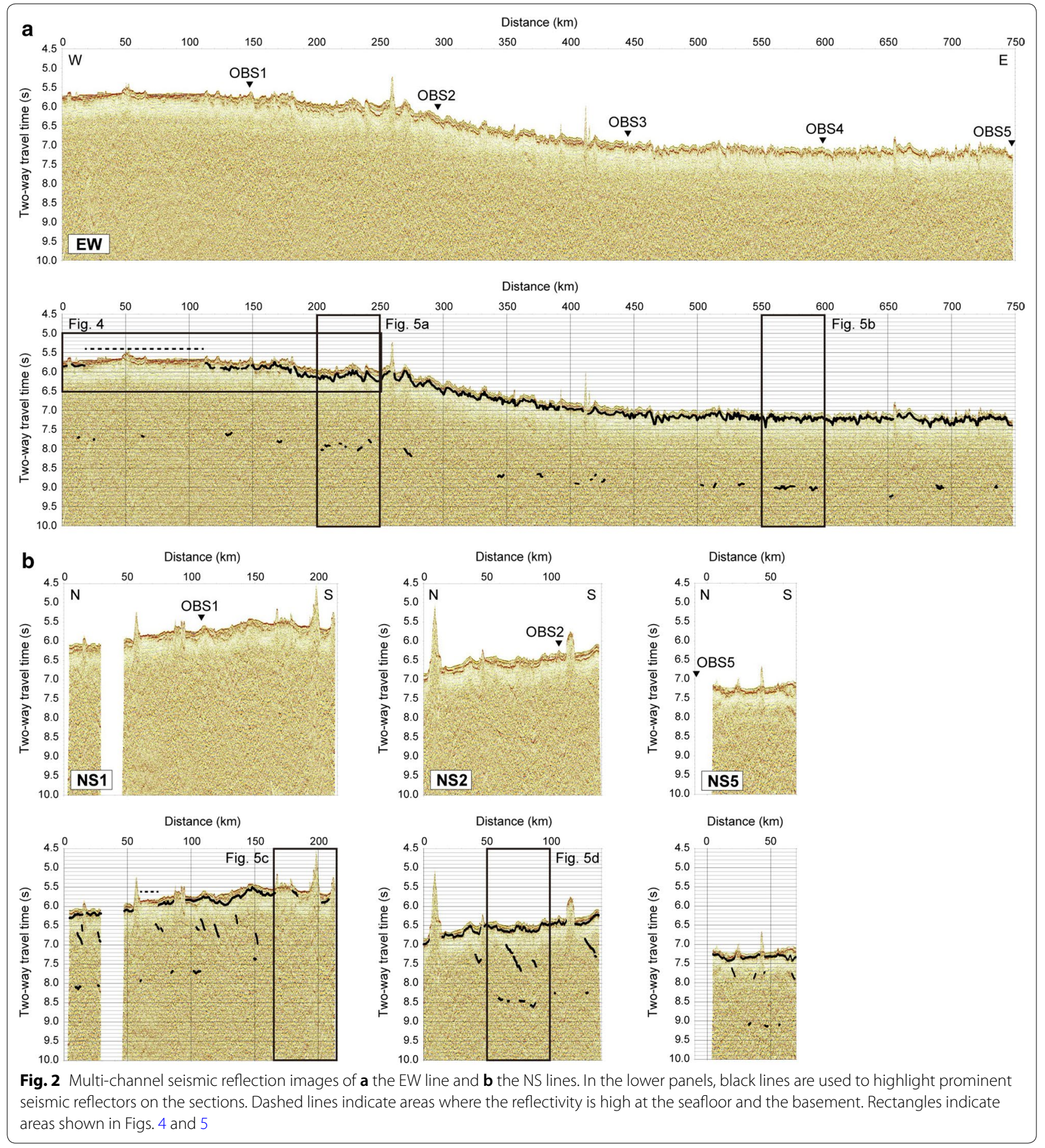



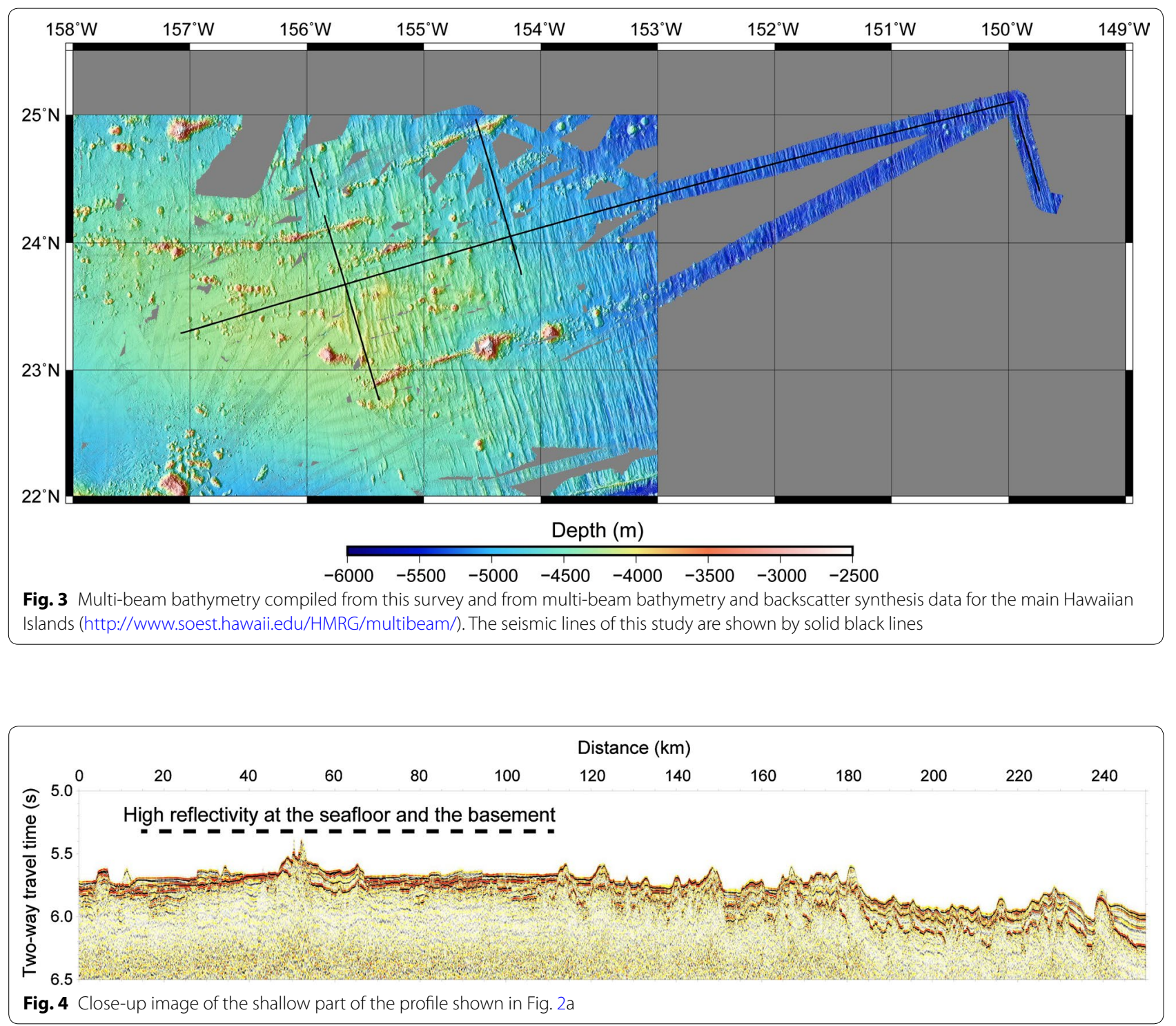

volcanic field identified by side-scan mapping (Normark et al. 1989; Clague et al. 1990, 2002). Figure 1 shows that the main lava flows are west of our survey lines and only a small area of the EW line goes through the flows; the NS1 line crosses a very small flow at its northern end. The igneous basement was observed continuously along the profiles except under knolls or seamounts, which were observed along both the EW and NS lines. Moho reflections, about two seconds below the basement, are discontinuous or unclear on the images (Figs. 2, 5). In addition, we imaged southward-dipping reflectors in the crust at irregular intervals along the NS lines (Figs. 2, 5). These reflectors do not directly offset the igneous basement, nor do they reach the Moho reflection.

\section{$P$-wave velocity structure of the crust and uppermost mantle}

On all OBS record sections, we observed refraction phases from oceanic layer 2 (P2), oceanic layer 3 (P3), and the uppermost mantle (Pn) as first arrivals (Figs. 6, 7). P2 and P3 were observed as first arrivals at offsets of up to about $30 \mathrm{~km}$ with an apparent velocity of $4.7-7.1 \mathrm{~km} / \mathrm{s}$. The apparent velocities of P3 are different between OBS1 section $(6.5-6.6 \mathrm{~km} / \mathrm{s})$ and other (OBS2-5) section (7.0$7.1 \mathrm{~km} / \mathrm{s}$ ) as shown in Fig. 8. One characteristic of the EW record section is that $\mathrm{Pn}$ appears at offsets of more than $250 \mathrm{~km}$ on all OBS sections: In particular, on the OBS5 section, Pn appears at an offset of more than $350 \mathrm{~km}$ with an apparent velocity of $8.5-8.8 \mathrm{~km} / \mathrm{s}$ (Fig. 6a). Along the NS lines, we identified Pn with an apparent velocity 


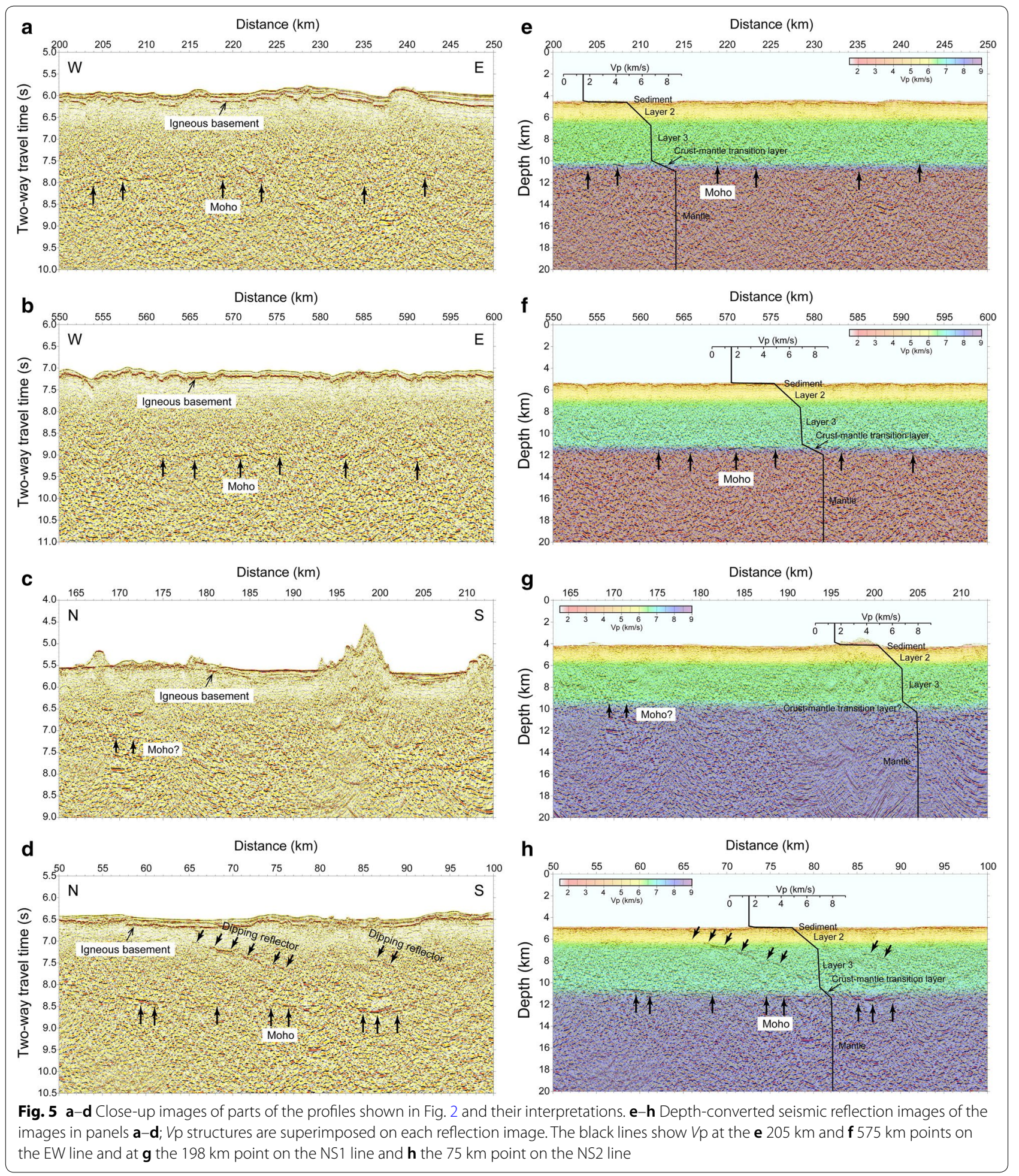

of $7.8-7.9 \mathrm{~km} / \mathrm{s}$, which is obviously different from the apparent velocity on the EW sections, although the offsets shown on the records are limited (Fig. 6b). Although we did not image a continuous and clear Moho reflection on the MCS sections, on the OBS records, we observed wide-angle reflection phases from the crust-mantle boundary. These phases are typically referred to as PmP, but here we call them Pt because we consider them to 

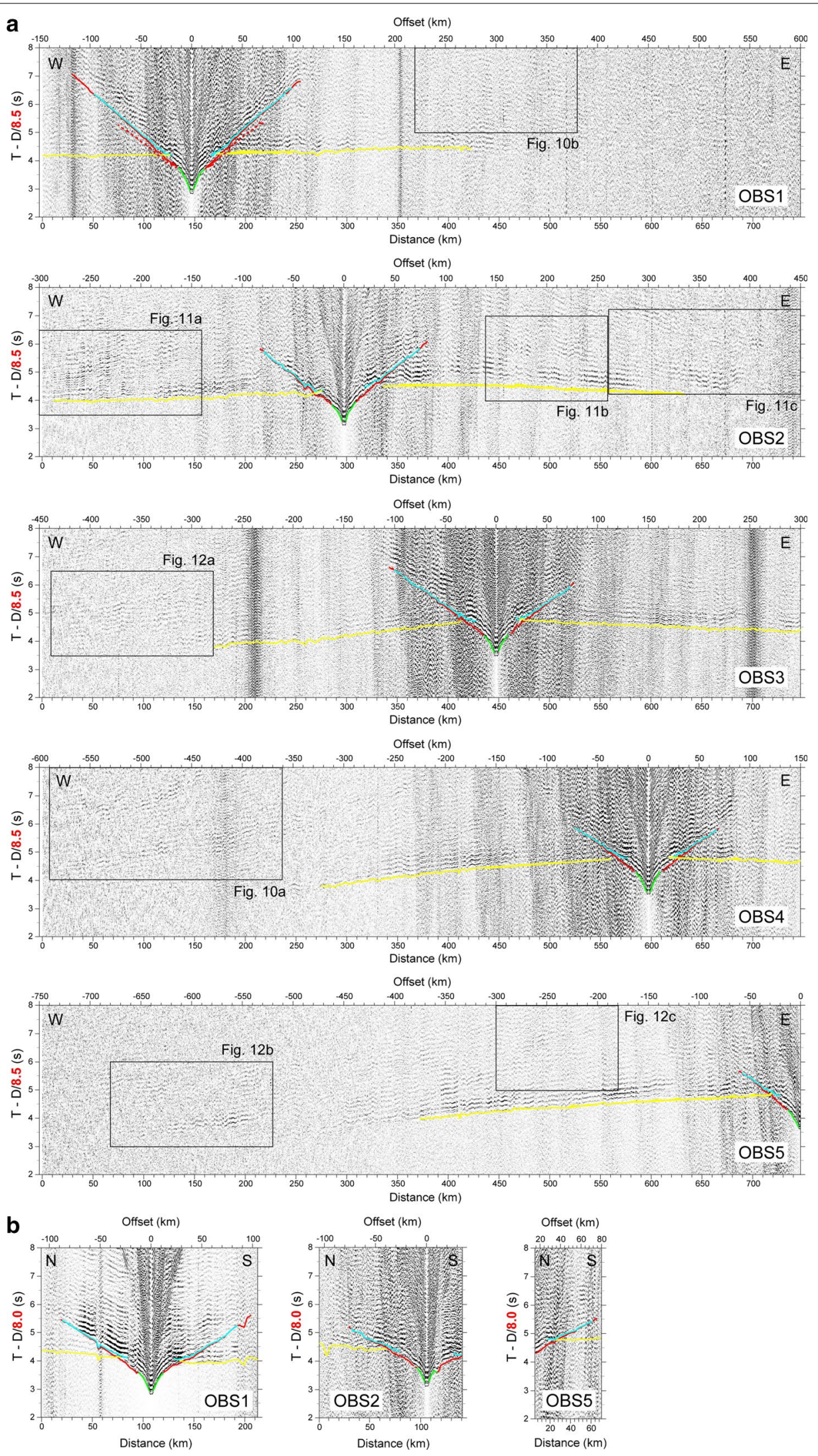
(See figure on previous page.)

Fig. 6 a Record sections covering an offset range of $750 \mathrm{~km}$ from OBS1-5 along the EW line. Reduction velocity is $8.5 \mathrm{~km} / \mathrm{s}$. b Record sections from OBS1, 2, and 5 along the NS1, NS2, and NS5 lines, respectively. Reduction velocity is $8.0 \mathrm{~km} / \mathrm{s}$. All observed waveforms were band-pass-filtered $(5-20 \mathrm{~Hz})$, and adjacent traces were stacked within an offset range of $200 \mathrm{~m}$ to improve the signal-to-noise ratio. The green, red, cyan, and yellow lines indicate the calculated travel times of P2, P3, Pt, and Pn, respectively. The dashed red line on the OBS1 record section along the EW line indicates the travel times of $\mathrm{P} 3$, which were calculated by using a velocity model without any decrease in crustal $\mathrm{VP}$

be generated by a crust-mantle transition layer in which $V \mathrm{p}$ gradually increases from the lowermost crust to the uppermost mantle (Ohira et al. 2017a). The high-amplitude Pt arrivals generally start to appear at an offset of $\sim 20 \mathrm{~km}$ on all records.

For the forward modeling, we constructed a starting model with a sedimentary layer, oceanic layer 2, oceanic layer 3 , and uppermost mantle by referring to the MCS sections. Then, even though the Moho reflection was unclear on the MCS sections, in addition to these four layers, we modeled a crust-mantle transition layer, because we observed clear Pt phases on the OBS records. Although clear Moho reflections occur locally (Figs. 2, 5), we modeled a crust-mantle transition layer with a thickness of $1 \mathrm{~km}$ along the entire profiles by referring to a previous seismic study conducted near Oahu (Lindwall 1988) and to ophiolite studies (e.g., Karson et al. 1984), because it is difficult to evaluate variations in the thickness of the transition layer from our survey data. We modeled the sedimentary layer by converting twoway travel times picked from the igneous basement in the MCS reflection section and using a velocity of 1.51$2.5 \mathrm{~km} / \mathrm{s}$ based on stacking velocities from the MCS data. We used the P2, P3, Pn, and Pt travel times to model the $V \mathrm{p}$ structure of the igneous crustal sections and uppermost mantle (Figs. 6, 7). The structure of the resulting model (Figs. 5, 9) is similar to that of typical oceanic crust in the old Pacific basin (White et al. 1992). The thickness of the crust, that is, the distance from the igneous basement to the middle of the crust-mantle transition layer, is $6.0-6.2 \mathrm{~km}$ along most of the profiles. However, $V \mathrm{p}$ in the oceanic crust is modeled as slower around OBS1 than around the other OBSs: Along the EW line, we estimated oceanic layer 2 to have $V \mathrm{p}=4.8-6.65 \mathrm{~km} / \mathrm{s}$ and oceanic layer 3 to have $V \mathrm{p}=6.65-6.7 \mathrm{~km} / \mathrm{s}$ at the distance range of $0-220 \mathrm{~km}$, whereas we modeled oceanic
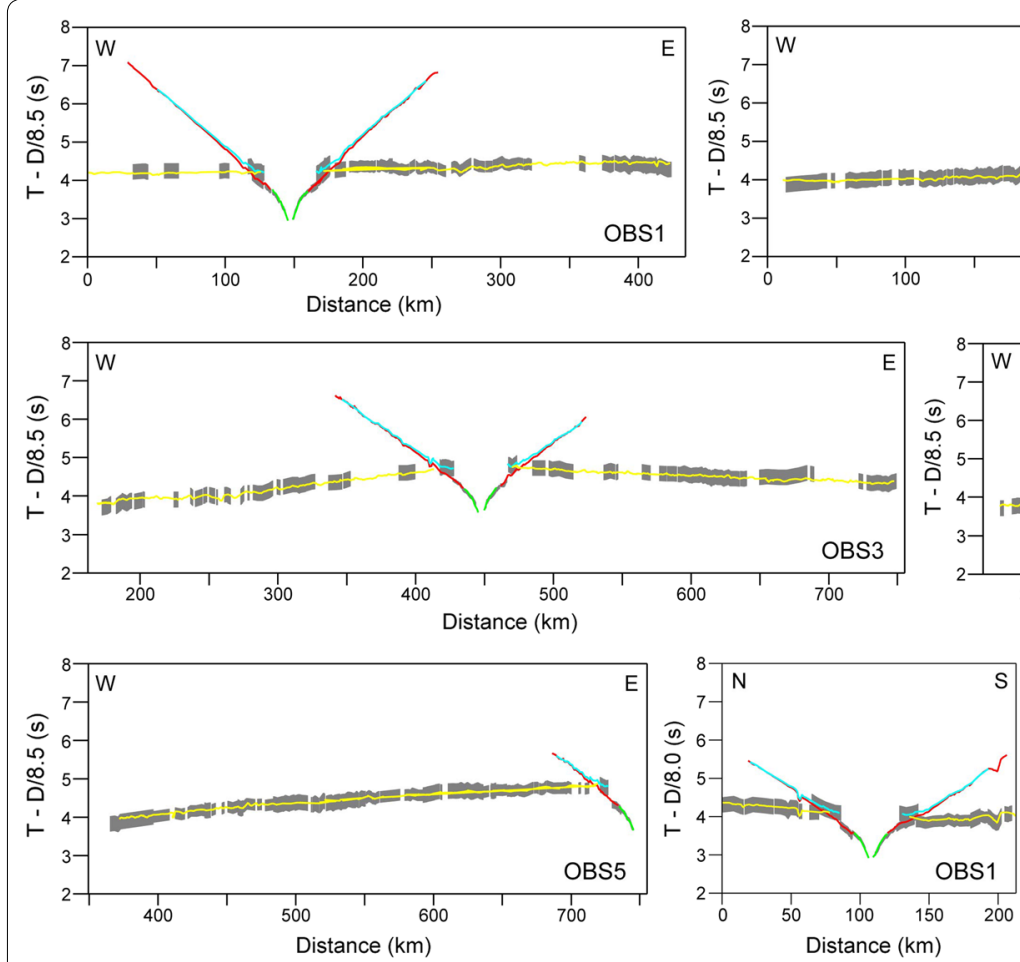

Fig. 7 Observed arrivals and calculated travel times for all OBSs. Vertical bars indicate the uncertainty of the observed arrivals. Reduction velocity is 8.5 and $8.0 \mathrm{~km} / \mathrm{s}$ along the EW line and the NS lines, respectively. The colors of the calculated travel time curves are explained in Fig. 6
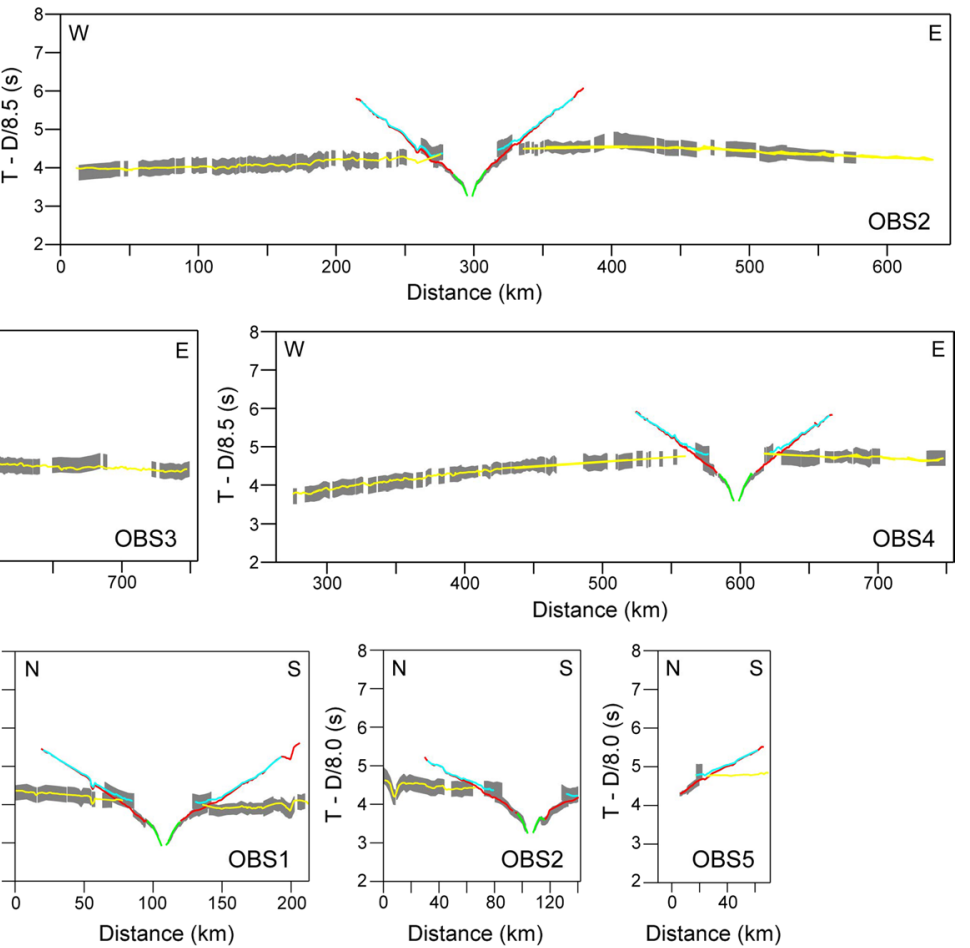


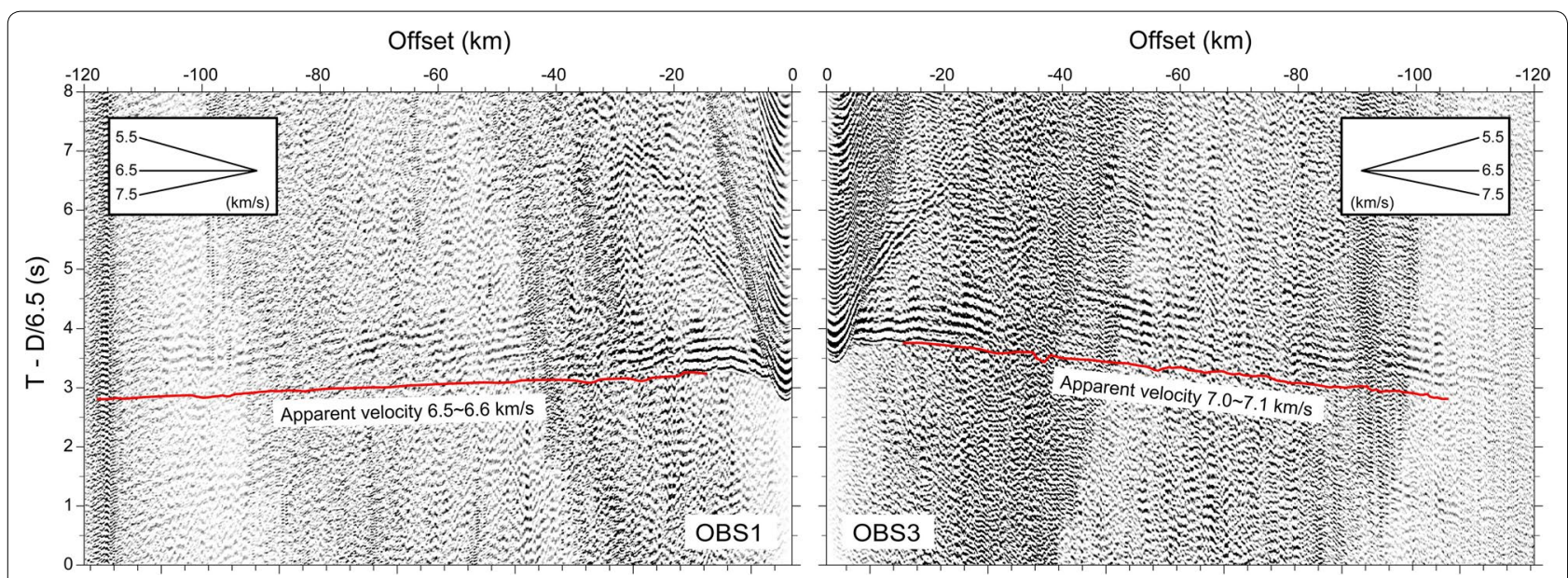

Fig. 8 Record sections from OBS1 and OBS3. Reduction velocity is $6.5 \mathrm{~km} / \mathrm{s}$. The red lines indicate the calculated travel times of P3

layer 2 to have $V \mathrm{p}=4.8-6.85 \mathrm{~km} / \mathrm{s}$ and oceanic layer 3 to have $V \mathrm{p}=6.85-7.0 \mathrm{~km} / \mathrm{s}$ at distances of $>220 \mathrm{~km}$ (Figs. 5 , 9). This difference in crustal $V \mathrm{p}$ along the $\mathrm{EW}$ line is significant because the travel times of P3, which were calculated by using a velocity model without any decrease in crustal $V \mathrm{p}$ over the distance range of $0-220 \mathrm{~km}$, did not explain the observed arrivals on the OBS1 record section along the EW line (dashed red line in Fig. 6a). Another remarkable observation is azimuthal anisotropy within the uppermost mantle; the apparent velocities of Pn arrivals are different between the EW line and the NS lines (Fig. 6). Thus, we modeled $V \mathrm{p}$ immediately below the Moho to be $8.5-8.65 \mathrm{~km} / \mathrm{s}$ along the EW line and $7.9-8.0 \mathrm{~km} / \mathrm{s}$ along the NS lines with an azimuthal anisotropy of $\sim 9 \%$ (Fig. 9).

\section{Reflectors in the oceanic lithosphere}

In addition to the crustal phases described above, we observed wide-angle reflection phases at large offsets that are like observations in other areas of the Pacific basin (Kaneda et al. 2010; Ohira et al. 2017b); we refer to these as reflection phases from deep reflectors (DRs). Along

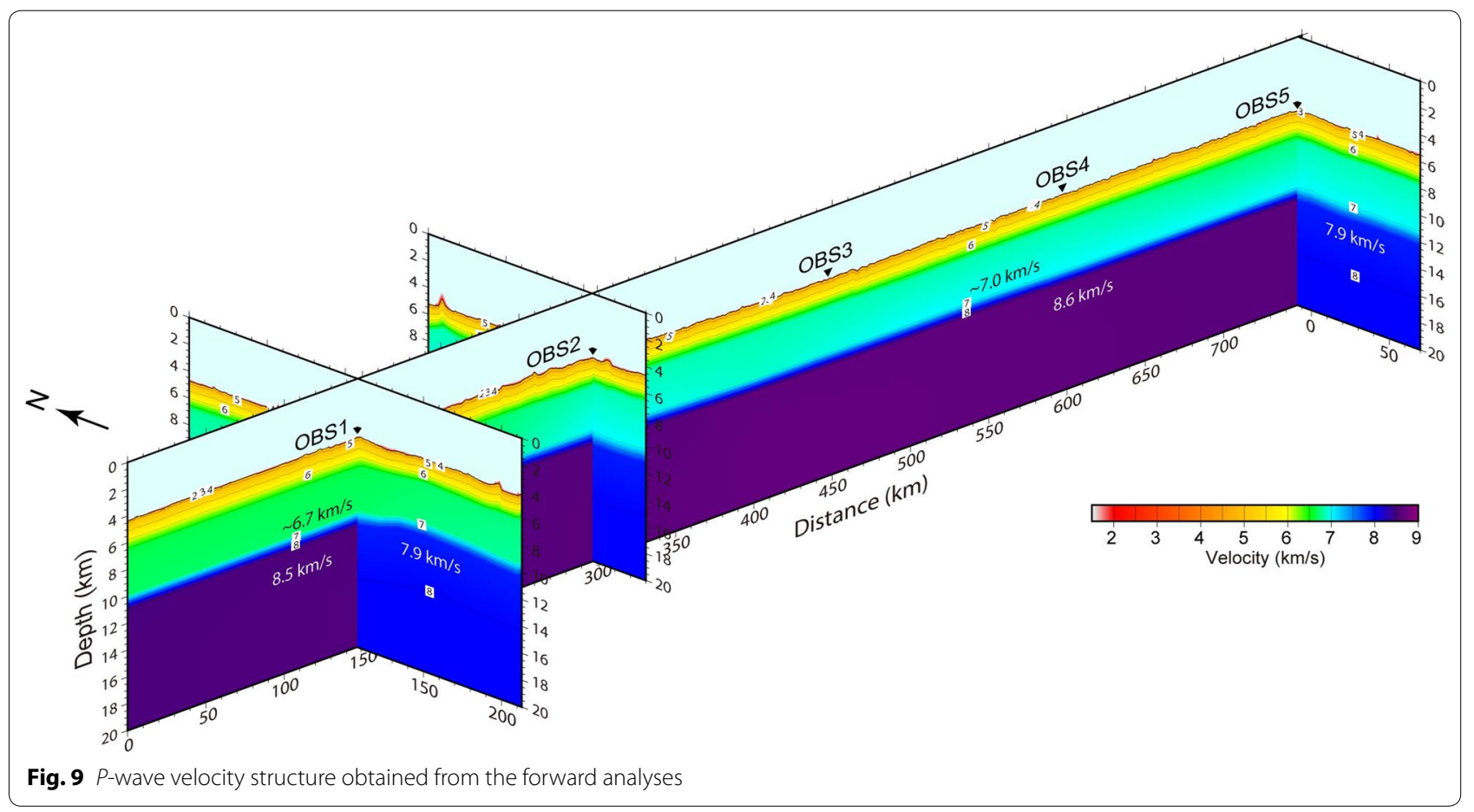


the EW line, we identified hyperbolic reflection arrivals at $4-7 \mathrm{~s}$ (arrows in Figs. 10,11,12) at an offset range from 160 to $660 \mathrm{~km}$.

Good examples of DRs were observed in the OBS2 record section. At offsets from -280 to $-160 \mathrm{~km}$, a DR appears at 4.7-5.3 s after the Pn arrival (Fig. 11a). On the other side of OBS2, DRs appear within the same offset range, but they are not continuous (Fig. 11b). In addition, at a larger offset $(\sim 415 \mathrm{~km})$, we observed a continuous DR extending over $>100 \mathrm{~km}$ at $5.7-6.7 \mathrm{~s}$ (Fig. 11c), and another DR at offsets from 330 to $380 \mathrm{~km}$ at around
$4.5 \mathrm{~s}$ (Fig. 11c). The DR at the largest offset in our survey appeared in the -660 to $-535 \mathrm{~km}$ offset range at 4.3$4.8 \mathrm{~s}$ on the OBS5 record (Fig. 12b). Meanwhile, the DR reflected from the largest depth was recorded by OBS4 at $5.9-6.8 \mathrm{~s}$ in the -575 to $-430 \mathrm{~km}$ offset range (Fig. 10a). We observed DRs with weak reflection amplitudes on the OBS1 and OBS3 record sections, in the $285-335 \mathrm{~km}$ offset range at $5.8-6.2 \mathrm{~s}$ and in the -390 to $-295 \mathrm{~km}$ offset range at $4.3-4.7 \mathrm{~s}$, respectively (Figs. 10b, 12a).

To estimate the DR reflection depths, we first carried out a travel time mapping analysis (Fujie et al. 2006),

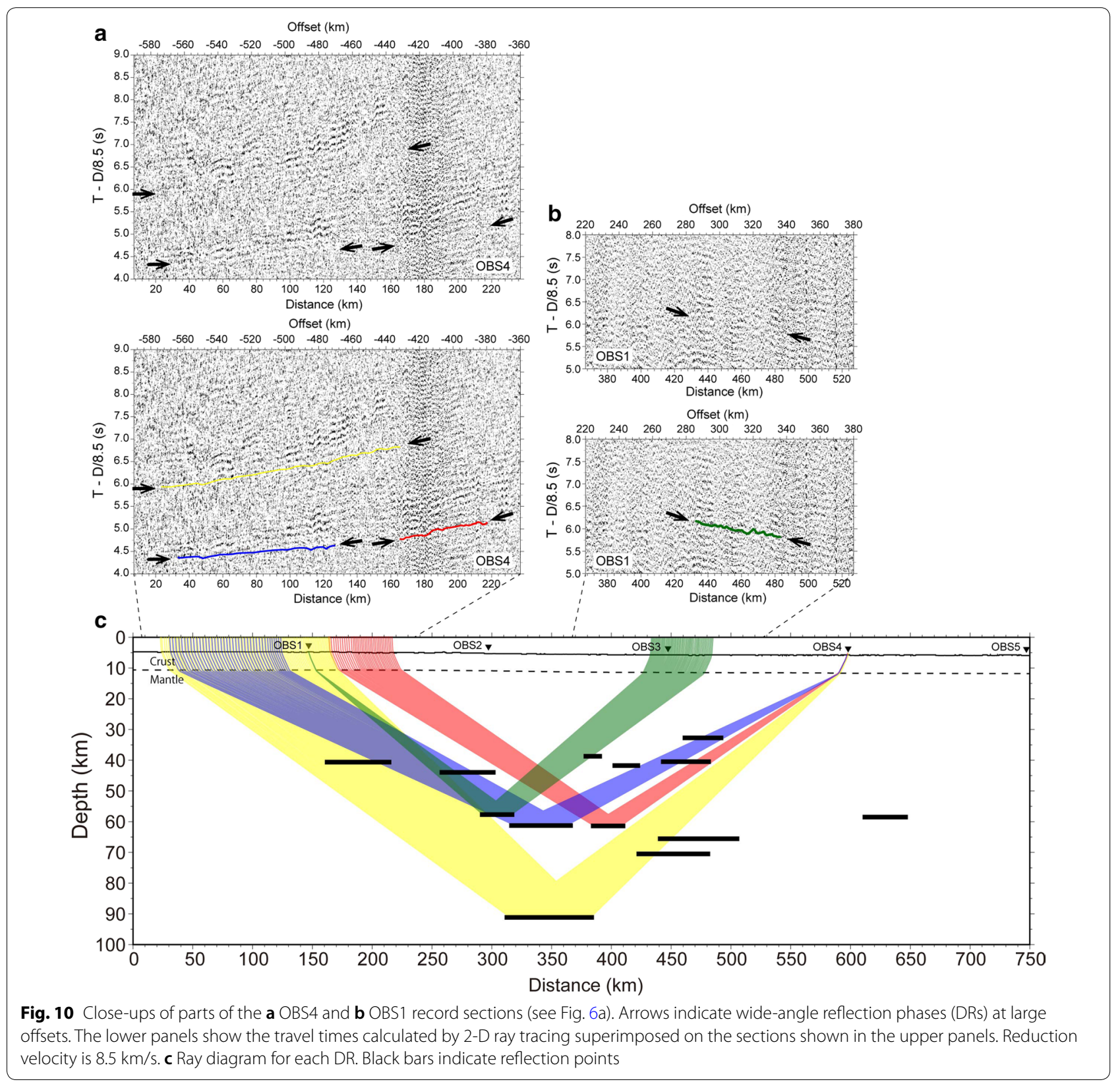




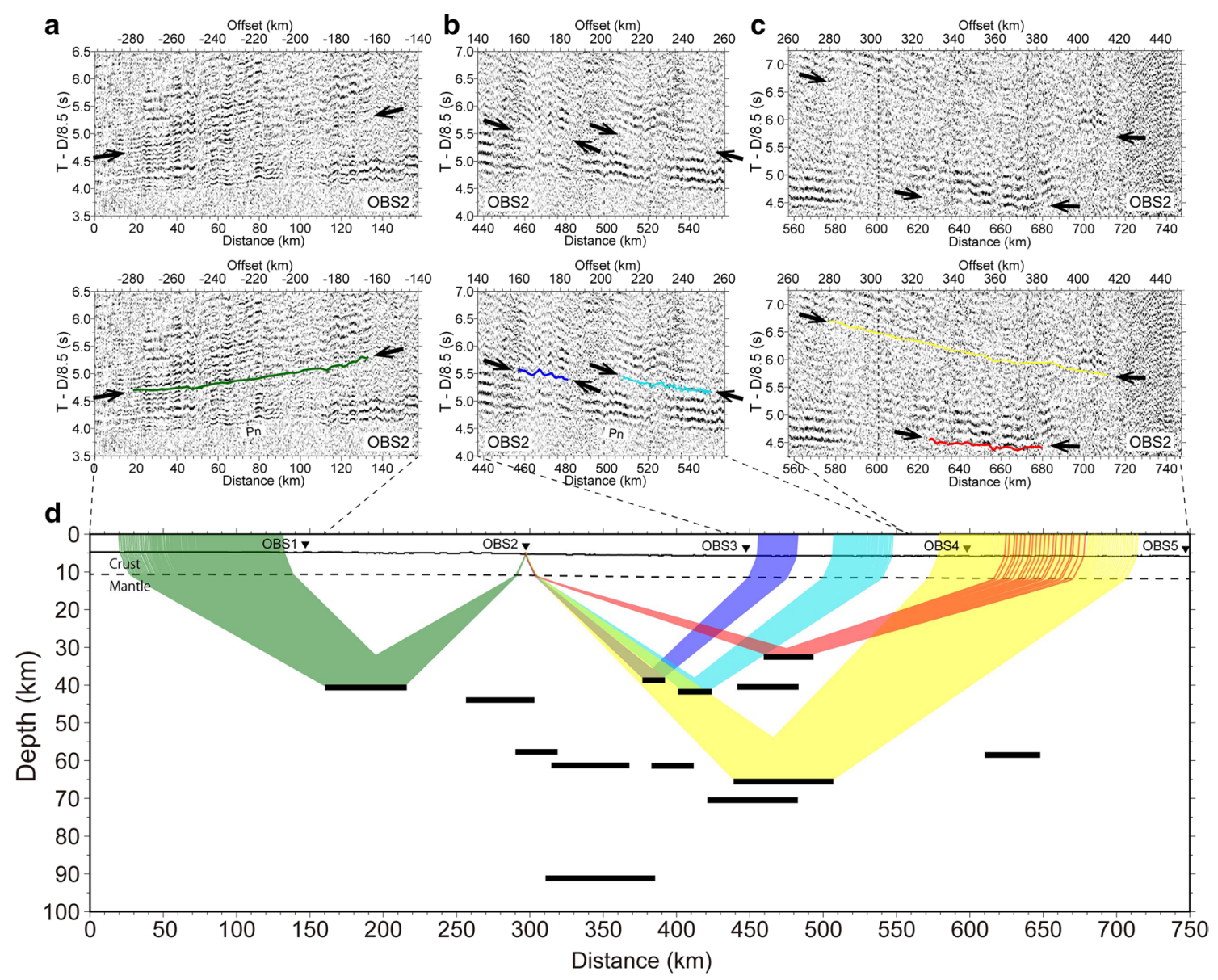

Fig. 11 a-c Close-up of OBS2 record sections (see Fig. 6a). Arrows indicate the wide-angle reflection phases (DRs) at large offsets. The travel times calculated from the 2-D ray tracing are superimposed on the record sections in the bottom panels. Reduction velocity is $8.5 \mathrm{~km} / \mathrm{s}$. Pn indicates refraction phases from the uppermost mantle. $\mathbf{d}$ Ray diagram for each DR. Black bars indicate reflection points

which is a method of projecting travel time picks onto the depth-distance domain from the time-distance domain based on the principles of the diffraction stack type of wide-angle prestack depth migration. Because it is hard to constrain $V \mathrm{p}$ in the mantle, which $\mathrm{Pn}$ waves do not penetrate, we extrapolated $V \mathrm{p}$ to the uppermost mantle following the method of Kaneda et al. (2010) and Ohira et al. (2017b) (Fig. 13). Second, by referring to the travel time mapping results, we applied 2-D ray tracing (Zelt and Smith 1992) to fit the DR observed and calculated arrivals. These calculated travel times are superimposed on the record sections shown in Figs. 10, 11, and 12 along with the ray diagrams and estimated reflection points for each DR.

Using the travel time analysis results, we estimated that mantle reflectors were mainly distributed at mid-lithosphere depths (30-65 km depth beneath the seafloor), except for one reflector at $85 \mathrm{~km}$ depth below the seafloor near the middle (310-385 km distance) of our EW profile observed on the OBS4 record (Figs. 10, 13).

\section{Discussion}

\section{Crustal and uppermost mantle structure}

In this section, we discuss the effect of the plume activity and the corresponding plate flexure on the crustal and uppermost mantle structure. Compared with Moho reflections acquired in the basin of the northwestern Pacific by using the same specifications with the R/V Kairei MCS system (e.g., Kodaira et al. 2014; Fujie et al. 2016), those obtained in this study were generally discontinuous or unclear. Nevertheless, the seismic velocity structure of the crust shows a Vp structure that is typical of old oceanic crust in the Pacific basin, formed during 29-140 Ma, according to data compiled by White et al. (1992). The crustal thickness estimated in our study is also approximately consistent with that of Pacific Ocean 


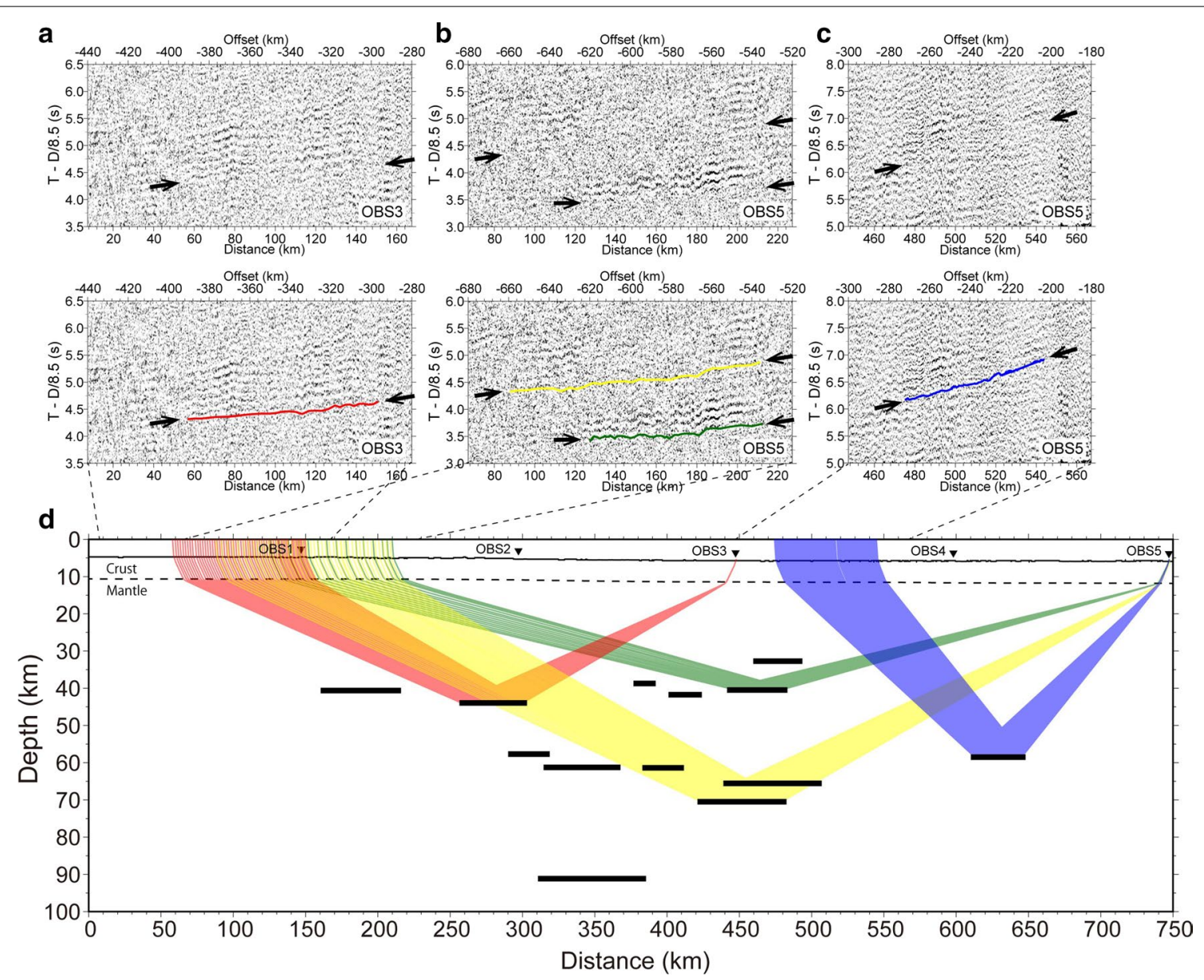

Fig. 12 a-c Close-ups of OBS3 and OSB5 record sections (see Fig. 6a). Arrows indicate wide-angle reflection phases (DRs) at large offsets. The travel times calculated from the 2-D ray tracing are superimposed on the record sections in the bottom panels. Reduction velocity is $8.5 \mathrm{~km} / \mathrm{s}$. Pn indicates refraction phases from the uppermost mantle. $\mathbf{d}$ Ray diagram for each DR. Black bars indicate reflection points

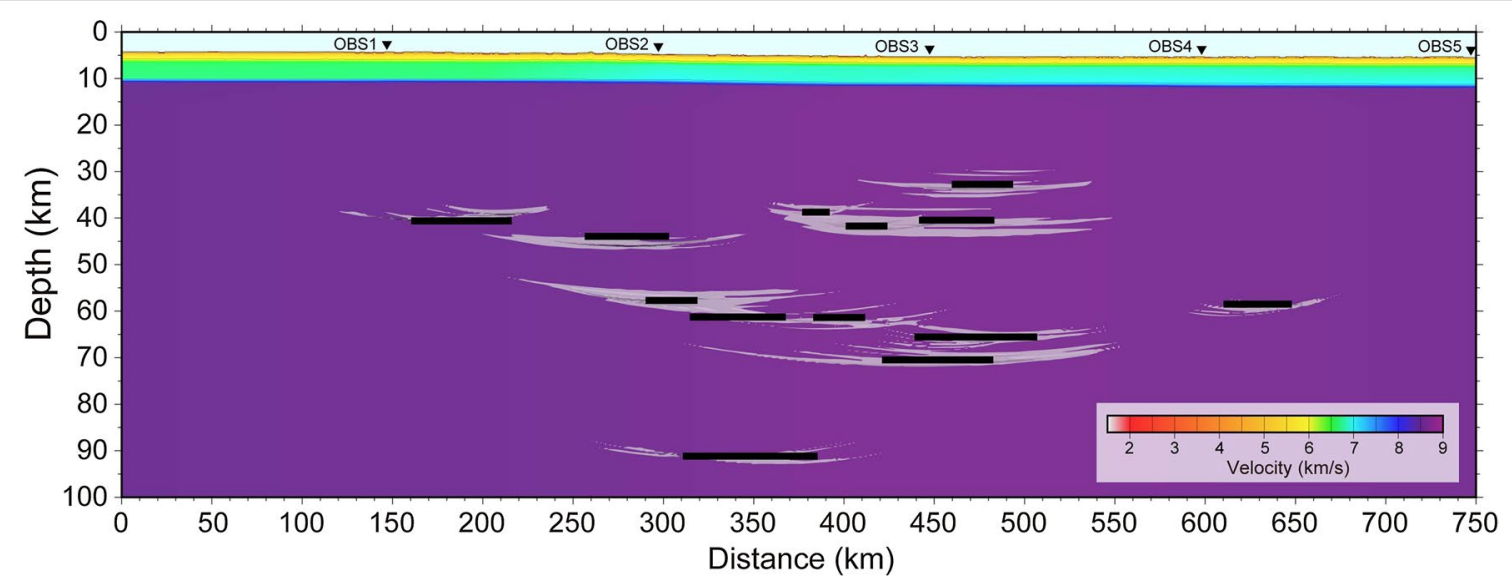

Fig. 13 Results of the travel time mapping and ray tracing for the DRs shown in Figs. 10, 11, and 12. The background $P$-wave velocity model was used to determine reflection travel time picks. Diffraction surfaces are shown as white curves. Black bars indicate reflection points for the DRs on all OBS records 
basin crust dating from 65 to 85 Ma reported by Van Avendonk et al. (2017). Thus, our data provide no evidence for substantial magmatic underplating due to plume activity beneath the northeastern Hawaiian Arch (e.g., Leahy et al. 2010). This observation is consistent with the results of previous active-source seismic surveys near our profiles (e.g., Shor and Pollard 1964; Watts et al. 1985). On the northeastern Hawaiian Arch, our results show that the depth from sea level to the middle of the crust-mantle transition layer is approximately $10.5 \mathrm{~km}$, which agrees with an earlier seismic refraction study (Shor and Pollard 1964). The crust-mantle transition zone observed along our profile instead of a clear Moho can be attributed mainly to two factors. One is the effect of plume activity. ten Brink and Brocher (1987) suggested that an anomalously thick (3-6 km) crust-mantle transition layer extends for a distance of $100 \mathrm{~km}$ both north and south from the center of Oahu. They interpreted this layer as an intrusive complex directly related to the magma upwelling and volcanism in the Hawaiian Islands. However, our observations do not indicate the direct effects of plume activity, because we observed an unclear Moho both around the arch at the western end of the EW profile and in the basin at its eastern end. Another possible interpretation is irregular magmatism related to the accretion of oceanic crust at a mid-ocean ridge. A seismic reflection study across the island of Hawaii reported that the Moho reflection is weaker north of the Hawaiian islands than to the south (Watts et al. 1985), and ten Brink and Brocher (1988) suggested that the temperature of the magma supply is lower north of the Molokai Fracture Zone (Fig. 1) than south of it. Therefore, the unclear Moho that we observed may reflect crustal formation conditions at a spreading center rather than the effect of hotspot volcanism.

The oceanic crust $V \mathrm{p}$, estimated from our OBS data, decreased slightly from the eastern to the western end of the profile (Fig. 9). In a refraction study, ten Brink and Brocher (1988) observed a structural variation of the oceanic crust around the Hawaiian Islands; namely, they found a significant difference $(1-2 \pm 1 \mathrm{~km})$ in crustal thickness between areas south and north of Oahu and suggested that this difference in crustal structure was generated during crustal formation by thermally induced compositional variations between two crustal segments separated by the Molokai Fracture Zone. However, our seismic profile does not cross the Molokai Fracture Zone, and the seafloor spreading rate along our profile is estimated to be almost constant (Müller et al. 2008).

On the other hand, our data indicate strong azimuthal anisotropy ( $9 \%)$ of $V \mathrm{p}$ in the uppermost mantle, with higher values in the direction of seafloor spreading. This observation suggests that the upper mantle preserves the alignment of olivine crystals induced by mantle flow at a mid-ocean ridge (Hess 1964; Zhang and Karato 1995). A large degree of azimuthal anisotropy is commonly observed in the uppermost mantle in regions created at a fast spreading center (e.g., Oikawa et al. 2010; Song and Kim 2012; Kodaira et al. 2014). For example, a seismic refraction survey in a section of the northwest Pacific basin, which was produced at a half-spreading rate of $>80 \mathrm{~mm}$ /year, observed a mantle $V \mathrm{p}$ of $8.5-8.7$ and $7.9 \mathrm{~km} / \mathrm{s}$ along lines parallel and perpendicular to the magnetic lineation, respectively; these values indicate an azimuthal anisotropy of $7-10 \%$ in the uppermost mantle (Oikawa et al. 2010). However, another area of the Pacific basin that was created at an intermediate spreading rate $(<40 \mathrm{~mm} /$ year) also showed high $\mathrm{Vp}$ of up to $8.6 \mathrm{~km} / \mathrm{s}$ in the uppermost mantle parallel to the direction of seafloor spreading, although the degree of azimuthal anisotropy was not constrained (Ohira et al. 2017a). Therefore, the azimuthal anisotropy of $\sim 9 \%$ observed in this study suggests that the strong anisotropy in the uppermost mantle is explained by not only a spreading rate but also some other factor.

In our data, the crustal $V \mathrm{p}$ under the North Arch is slower than that in the basin beneath OBS3-5, although the anisotropy observed in the uppermost mantle does not vary much along the profile, which suggests that the uppermost mantle preserves the original structure formed at the mid-ocean ridge. It is possible that the decrease in crustal Vp under the North Arch is an effect of higher temperatures due to plume activity. However, to explain our observed $0.2-0.3 \mathrm{~km} / \mathrm{s}$ decrease in crustal $V$ p, a lateral temperature contrast of more than $400{ }^{\circ} \mathrm{C}$ is needed (Christensen 1979). However, the mantle temperature anomaly predicted from the crustal structure obtained by a receiver function study mostly indicated a temperature contrast of less than $200{ }^{\circ} \mathrm{C}$ along our seismic lines (Leahy et al. 2010); thus, it is difficult to interpret the decrease in crustal $V \mathrm{p}$ under the North Arch as a thermal effect of plume activity. Another possible explanation is a mechanical effect caused by flexure of the lithosphere. Watts et al. (1980) inferred the existence of bending stress near Oahu in the Hawaiian Islands from the effective elastic thickness of the oceanic lithosphere. They reported a maximum tensile stress of $2.8 \mathrm{kbar}$ to the north of Oahu, in the flanking region, due to loading of the islands. Brocher and ten Brink (1987) reported that in the Hawaiian Arch, the average $V p$ in oceanic layer 2 is lowered by $0.8-0.9 \mathrm{~km} / \mathrm{s}$, and they interpreted the lower velocities within the arch to be related to increased extensional strains and crack opening caused by a lithospheric flexure. Although we found a velocity decrease of only $0.2-0.3 \mathrm{~km} / \mathrm{s}$ in layer 2 and layer 3 , the flexure of the lithosphere likely at least contributed to the observed 
crustal velocity variation. As for the mantle structure, $V p$ in the uppermost mantle is slightly lower (approximately $0.1 \mathrm{~km} / \mathrm{s}$ ) under the North Arch than beneath the basin (Fig. 9). This small variation in mantle velocity may also relate to the lithospheric flexure; however, a more dense refraction survey than that obtained with our sparsely deployed OBSs is needed to detect structural variations of the crust and mantle in more detail.

\section{Heterogeneity in the oceanic lithosphere}

In addition to the crustal and uppermost mantle seismic structure, we detected signals from the deeper lithospheric mantle at $30-85 \mathrm{~km}$ depth in the large-offset seismic profile. Similar wide-angle reflection phases from the deep lithospheric mantle near hotspots have been reported by Gallart et al. (1999), who observed strong, late arrivals $0.5-1.5 \mathrm{~s}$ after the Pn phase along a $250-\mathrm{km}$ long seismic transect across the oceanic island of La Réunion. Their records show localized velocity heterogeneities in the lithospheric mantle in the $25-45 \mathrm{~km}$ depth range. Smallwood et al. (1999) also observed a mantle reflector at $52 \mathrm{~km}$ depth beneath Iceland in an activesource survey.

Our large-offset OBS data revealed reflectors distributed at depths of $30-85 \mathrm{~km}$ in the mantle. If we assume that these reflectors represent heterogeneities that originate from some kind of compositional boundary (Gallart et al. 1999; Smallwood et al. 1999), two major interpretations are possible. One interpretation is that the heterogeneities are remnants of intraplate igneous activities such as the top of a zone of partial mantle melting or part of a hotspot plume head (Kaneda et al. 2010). Kaneda et al. (2010) observed reflected waves from depths of 30-45 km beneath the Marcus-Wake seamount chain, and they interpreted the reflectors to have originated from intraplate igneous activity. However, we detected mantle reflectors beneath the normal ocean basin, where crustal thickening due to intraplate volcanism does not occur. The other interpretation is that the mantle reflectors represent quasi-laminate heterogeneities in the lithospheric mantle; such heterogeneities have been identified previously by analyzing $P o$ and $S o$ waves, which are characterized by their high-frequency $(>2.5 \mathrm{~Hz})$ content and their propagation for great distances in the oceanic lithosphere, with quasi-laminate features with a horizontal correlation length of around $10 \mathrm{~km}$ and a vertical correlation length of $0.5 \mathrm{~km}$ and a velocity perturbation of a few percent (e.g., Shito et al. 2015; Kennett and Furumura 2015). These heterogeneities are considered to have formed continuously in the oceanic lithosphere from the time of its formation at a mid-ocean ridge via the solidification of melts attached to the bottom of the lithosphere
(Shito et al. 2015). In a previous active-source seismic survey conducted southeast of the Shatsky Rise, we observed such frozen melts at depths of 37-59 km (Ohira et al. 2017b), but based on that study we were unable to determine whether such heterogeneities are ubiquitous in the lithosphere or restricted to specific regions. The identification in this study of similar reflectors in another tectonic region may support the possibility that such heterogeneities are universal within the oceanic lithosphere.

\section{Conclusions}

We inferred the crustal and uppermost mantle seismic structure of the northeastern Hawaiian Arch from seismic reflection and refraction data. In both the ocean basin and the Hawaiian Arch, the inferred crustal structure is typical structure of oceanic crust, which suggests that crustal underplating due to intraplate volcanism has not occurred along our seismic profile. Although Moho reflections in the MCS reflection section are unclear along most parts of the profile, $V \mathrm{p}$ in the uppermost mantle shows strong azimuthal anisotropy, which indicates that the original uppermost mantle structure formed at a mid-oceanic ridge is preserved, even near the hotspot. In addition, we observed wide-angle reflection waves at large offsets on the OBS records and inferred that they were reflected from heterogeneities within the oceanic lithosphere distributed in the mantle at depths of $30-85 \mathrm{~km}$.

\section{Abbreviations}

OBS: ocean-bottom seismometer; MCS: multi-channel seismic; DR: reflection phases from deep reflector; PLUME: the Hawaiian Plume-Lithosphere Undersea Melt Experiment; 1-D: one-dimensional; 2-D: two-dimensional; Ma: million years ago; $V$ p: $P$-wave velocity.

\section{Authors' contributions}

$\mathrm{AO}$ processed and interpreted the data and wrote the manuscript. SK supervised AO's work. SK and GFM led the survey planning. SM, GF, and MY contributed to the survey planning. MY, TF, and YK contributed to the seismic data acquisition. All authors read and approved the final manuscript.

\section{Author details}

1 Japan Agency for Marine-Earth Science and Technology (JAMSTEC), Showa-machi 3173-25, Kanazawa-ku, Yokohama 236-0001, Japan. ${ }^{2}$ Yokohama National University, Tokiwadai 79-1, Hodogaya-ku, Yokohama 240-8501, Japan. ${ }^{3}$ University of Hawaii, 1680 East-West Rd., POST 813, Honolulu, HI 96822, USA. ${ }^{4}$ Japan Agency for Marine-Earth Science and Technology (JAMSTEC), Natsushima-cho 2-15, Yokosuka 237-0061, Japan.

\section{Acknowledgements}

We thank the captain, crew, and technical staff of RN Langseth, RN Kairei, and R/V Kilo Moana. We thank K. Suyehiro, K. Moe, S. Umino, A. d.C. Perez, and Y. Kusano for data acquisition. Figures in this paper were produced with the GMT graphic package of Wessel et al. (2013).

\section{Competing interests}

The authors declare that they have no competing interests. 


\section{Availability of data and materials}

In accordance with JAMSTEC's data policy, all data acquired in this study will be available 2 years after the end date of the cruise at the JAMSTEC database site (https://www.jamstec.go.jp/jamstec-e/IFREE_center/index-e.html).

\section{Consent for publication}

Not applicable.

\section{Ethics approval and consent to participate}

Not applicable.

\section{Funding}

This work was supported by a research fund of the Japan Agency for MarineEarth Science and Technology (JAMSTEC) and US National Science Foundation Grant OCE-1355468 to the University of Hawaii.

\section{Publisher's Note}

Springer Nature remains neutral with regard to jurisdictional claims in published maps and institutional affiliations.

Received: 15 April 2018 Accepted: 10 July 2018

Published online: 16 July 2018

\section{References}

Ballmer MD, Ito G, van Hunen J, Tackley PJ (2011) Spatial and temporal variability in Hawaiian hotspot volcanism induced by small-scale convection. Nat Geosci 4:457-460. https://doi.org/10.1038/ngeo1187

Brocher TM, ten Brink US (1987) Variations in oceanic layer 2 elastic velocities near Hawaii and their correlation to lithospheric flexure. J Geophys Res 92:2647-2661. https://doi.org/10.1029/JB092iB03p02647

Christensen NI (1979) Compressional wave velocities in rocks at high temperatures and pressures, critical thermal gradients, and crustal low-velocity zones. J Geophys Res 84:6849-6857. https://doi.org/10.1029/JB084iB12p 06849

Clague DA, Dixon JE (2000) Extrinsic controls on the evolution of Hawaiian ocean island volcanoes. Geochem Geophys Geosyst. https://doi. org/10.1029/1999GC000023

Clague DA, Holcomb RT, Sinton JM, Detrick RS, Torresan ME (1990) Pliocene and Pleistocene alkalic flood basalts on the seafloor north of the Hawaiian Islands. Earth Planet Sci Lett 98:175-191. https://doi. org/10.1016/0012-821X(90)90058-6

Clague DA, Uto K, Satake K, Davis AS (2002) Eruption style and flow emplacement in the submarine North Arch Volcanic Field, Hawaii. Hawaii Volcanoes Deep Underw Perspect. https://doi.org/10.1029/GM128p0065

Crough ST (1978) Thermal origin of mid-plate hot-spot swells. Geophys J Int 55:451-469. https://doi.org/10.1111/j.1365-246X.1978.tb04282.x

Dixon JE, Clague DA, Wallace P, Poreda R (1997) Volatiles in alkalic basalts form the North Arch Volcanic Field, Hawaii: extensive degassing of deep submarine-erupted alkalic series lavas. J Petrol 38:911-939. https://doi. org/10.1093/petroj/38.7.911

Frey FA, Clague D, Mahoney JJ, Sinton JM (2000) Volcanism at the edge of the Hawaiian plume: petrogenesis of submarine alkalic lavas from the North Arch volcanic field. J Petrol 41:667-691. https://doi.org/10.1093/petro $\log / 41.5 .667$

Fujie G, Ito A, Kodaira S, Takahashi N, Kaneda Y (2006) Confirming sharp bending of the Pacific plate in the northern Japan trench subduction zone by applying a traveltime mapping method. Phys Earth Planet Inter 157:72-85. https://doi.org/10.1016/j.pepi.2006.03.013

Fujie G, Kasahara J, Murase K, Mochizuki K, Kaneda Y (2008) Interactive analysis tools for the wide-angle seismic data for crustal structure study (Technical Report). Explor Geophys 39:26-33. https://doi.org/10.1071/EG08006

Fujie G, Kodaira S, Sato T, Takahashi T (2016) Along-trench variations in the seismic structure of the incoming Pacific plate at the outer rise of the northern Japan Trench. Geophys Res Lett 43:666-673. https://doi. org/10.1002/2015GL067363

Gallart J, Driad L, Charvis P, Sapin M, Hirn A, Diaz J, Voogd BD, Sachpazi M (1999) Perturbation to the lithosphere along the hotspot track of La
Réunion from an offshore-onshore seismic transect. J Geophys Res 104:2895-2908. https://doi.org/10.1029/98JB02840

Hess HH (1959) The AMSOC hole to the Earth's mantle. Eos Trans Am Geophys Union 40:340-345

Hess HH (1964) Seismic anisotropy of the uppermost mantle under oceans. Nature 203:629-631

Hill DP (1969) Crustal structure of the island of Hawaii from seismic-refraction measurements. Bull Seismol Soc Am 59:101-130

Hill DP, Zucca JJ (1987) Geophysical constraints on the structure of Kilauea and Mauna Loa volcanoes and some implications for seismomagmatic processes. US Geol Surv Prof Pap 1350:903-917

Holcomb RT, Robinson JE (2004) Maps of Hawaiian Islands exclusive economic zone interpreted from GLORIA Sidescan-Sonar Imagery, scale 1:2,000,000. U.S. Geol. Surv, Washington

Ildefonse B, Abe N, Blackman DK, Canales JP, Isozaki Y, Kodaira S, Myers G, Nakamura K, Nedimovic M, Skinner AC, Seama N, Takazawa E, Teagle DAH, Tominaga M, Umino S, Wilson DS, Yamao M (2010) The MoHole: a crustal journey and mantle quest, workshop in Kanazawa, Japan, 3-5 June 2010. Sci Drill 10:56-63. https://doi.org/10.2204/iodp.sd.10.07.2010

Kaneda K, Kodaira S, Nishizawa A, Morishita T, Takahashi N (2010) Structural evolution of preexisting oceanic crust through intraplate igneous activities in the Marcus-Wake seamount chain. Geochem Geophys Geosyst. https://doi.org/10.1029/2010GC003231

Karson JA, Collins JA, Casey JF (1984) Geologic and seismic velocity structure of the crust/mantle transition in the Bay of Islands ophiolite complex. J Geophys Res 89:6126-6138. https://doi.org/10.1029/JB089iB07p06126

Kennett BLN, Furumura T (2015) Toward the reconciliation of seismological and petrological perspectives on oceanic lithosphere heterogeneity. Geochem Geophys Geosyst 16:3129-3141. https://doi. org/10.1002/2015GC006017

Kodaira S, Fujie G, Yamashita M, Sato T, Takahashi T, Takahashi N (2014) Seismological evidence of mantle flow driving plate motions at a palaeo-spreading centre. Nat Geosci 7:371-375. https://doi.org/10.1038/ngeo2121

Laske G, Markee A, Orcutt JA, Wolfe CJ, Collins JA, Solomon SC, Detrick RS, Bercovici D, Hauri EH (2011) Asymmetric shallow mantle structure beneath the Hawaiian Swell-evidence from Rayleigh waves recorded by the PLUME network. Geophys J Int 187:1725-1742. https://doi.org/10.1111/ j.1365-246X.2011.05238.X

Leahy GM, Collins JA, Wolfe CJ, Laske G, Solomon SC (2010) Underplating of the Hawaiian Swell: evidence from teleseismic receiver functions. Geophys J Int 183:313-329. https://doi.org/10.1111/j.1365-246X.2010.04720.x

Lindwall DA (1988) A two-dimensional seismic investigation of crustal structure under the Hawaiian Islands near Oahu and Kauai. J Geophys Res 93:12107-12122. https://doi.org/10.1029/JB093iB10p12107

Moore JG (1970) Relationship between subsidence and volcanic load, Hawaii. Bull Volcanol 34:562-576. https://doi.org/10.1007/BF02596771

Morgan WJ (1971) Convection plumes in the lower mantle. Nature 230:42. https://doi.org/10.1038/230042a0

Müller RD, Sdrolias M, Gaina C, Roest WR (2008) Age, spreading rates, and spreading asymmetry of the world's ocean crust. Geochem Geophys Geosyst. https://doi.org/10.1029/2007GC001743

Normark WR, Holcomb RT, Searle RC, Somer ML, Gutmacher CE (1989) Cruise report: Hawaiian GLORIA Legs 3 and 4, F3-88-HW and F4-88-HW, US Geol. Surv. Open File Rep, 89-213

Ohira A, Kodaira S, Nakamura Y, Fujie G, Arai R, Miura S (2017a) Structural variation of the oceanic Moho in the Pacific plate revealed by active-source seismic data. Earth Planet Sci Lett 476:111-121. https://doi.org/10.1016/j. epsl.2017.08.004

Ohira A, Kodaira S, Nakamura Y, Fujie G, Arai R, Miura S (2017b) Evidence for frozen melts in the mid-lithosphere detected from active-source seismic data. Sci Rep 7:15770. https://doi.org/10.1038/s41598-017-16047-4

Oikawa M, Kaneda K, Nishizawa A (2010) Seismic structures of the 154-160 Ma oceanic crust and uppermost mantle in the Northwest Pacific Basin. Earth Planets Space 62:e13-e16. https://doi.org/10.5047/eps.2010.02.011

Ribe NM (2004) Earth science: through thick and thin. Nature 427:793. https:// doi.org/10.1038/427793a

Rychert CA, Laske G, Harmon N, Shearer PM (2013) Seismic imaging of melt in a displaced Hawaiian plume. Nat Geosci 6:657-660. https://doi. org/10.1038/ngeo1878 
Shito A, Suetsugu D, Furumura T (2015) Evolution of the oceanic lithosphere inferred from Po/So waves traveling in the Philippine Sea Plate. J Geophys Res 120:5238-5248. https://doi.org/10.1002/2014JB011814

Shor GG, Pollard DD (1964) Mohole site selection studies north of Maui. J Geophys Res 69:1627-1637. https://doi.org/10.1029/JZ069i008p01627

Smallwood JR, Staples RK, Richardson KR, White RS (1999) Crust generated above the Iceland mantle plume: from continental rift to oceanic spreading center. J Geophys Res 104:22885-22902. https://doi. org/10.1029/1999JB900176

Song TRA, Kim Y (2012) Anisotropic uppermost mantle in young subducted slab underplating Central Mexico. Nat Geosci 5:55-59. https://doi. org/10.1038/ngeo1342

ten Brink US, Brocher TM (1987) Multichannel seismic evidence for a subcrustal intrusive complex under Oahu and a model for Hawaiian volcanism. J Geophys Res 92:13687-13707. https://doi.org/10.1029/JB092iB13p13687

ten Brink US, Brocher TM (1988) Multichannel seismic evidence for variations in crustal thickness across the Molokai Fracture Zone in the Mid-Pacific. J Geophys Res 93:1119-1130. https://doi.org/10.1029/JB093iB02p01119

The multibeam bathymetry and backscatter synthesis for the main Hawaiian Islands. http://www.soest.hawaii.edu/HMRG/multibeam/. Accessed 14 June 2018

Van Avendonk HJ, Davis JK, Harding JL, Lawver LA (2017) Decrease in oceanic crustal thickness since the breakup of Pangaea. Nat Geosci 10:58-61. https://doi.org/10.1038/NGEO2849

Watts AB, ten Brink US (1989) Crustal structure, flexure, and subsidence history of the Hawaiian Islands. J Geophys Res 94:10473-10500. https://doi. org/10.1029/JB094iB08p10473

Watts AB, Bodine JH, Steckler MS (1980) Observations of flexure and the state of stress in the oceanic lithosphere. J Geophys Res 85:6369-6376. https:// doi.org/10.1029/JB085iB11p06369
Watts AB, ten Brink US, Buhl P, Brocher TM (1985) A multichannel seismic study of lithospheric flexure across the Hawaiian-Emperor seamount chain. Nature 315:105. https://doi.org/10.1038/315105a0

Wessel P, Smith WHF, Scharroo R, Luis J, Wobbe F (2013) Generic mapping tools: improved version released. EOS Trans AGU 94(45):409-420

White RS, McKenzie D, O'Nions RK (1992) Oceanic crustal thickness from seismic measurements and rare earth element inversions. J Geophys Res 97:19683-19715. https://doi.org/10.1029/92JB01749

Wilson JT (1963) A possible origin of the Hawaiian Islands. Can J Phys 41:863-870. https://doi.org/10.1139/p63-094

Wolfe CJ, Solomon SC, Laske G, Collins JA, Detrick RS, Orcutt JA, Bercovici D, Hauri EH (2009) Mantle shear-wave velocity structure beneath the Hawaiian hot spot. Science 326:1388-1390. https://doi.org/10.1126/scien ce.1180165

Yang HJ, DA FreyFA C (2003) Constraints on the source components of lavas forming the Hawaiian North Arch and Honolulu Volcanics. J Petrol 44:603-627. https://doi.org/10.1093/petrology/44.4.603

Zelt CA, Smith RB (1992) Seismic traveltime inversion for 2-D crustal velocity structure. Geophys J Int 108:16-34. https://doi.org/10.1111/j.1365246X.1992.tb00836.X

Zhang S, Karato SI (1995) Lattice preferred orientation of olivine aggregates deformed in simple shear. Nature 375:774. https://doi.org/10.1038/37577 $4 \mathrm{a} 0$

Zucca JJ, Hill DP (1980) Crustal structure of the southeast flank of Kilauea volcano, Hawaii, from seismic refraction measurements. Bull Seismol Soc Am 70:1149-1159

Zucca JJ, Hill DP, Kovach RL (1982) Crustal structure of Mauna Loa volcano, Hawaii, from seismic refraction and gravity data. Bull Seismol Soc Am 72:1535-1550

\section{Submit your manuscript to a SpringerOpen ${ }^{\circ}$ journal and benefit from:}

- Convenient online submission

- Rigorous peer review

- Open access: articles freely available online

- High visibility within the field

- Retaining the copyright to your article

Submit your next manuscript at $\boldsymbol{\nabla}$ springeropen.com 